\title{
Properties, bioactive potential and extraction processes of glycosaminoglycans: an overview
}

\author{
Evellin Balbinot-Alfaro ${ }^{1 *(D)}$ Meritaine da Rocha $^{2}(\mathbb{D})$ \\ Alexandre da Trindade Alfaro ${ }^{3}$ Vilásia Guimarães Martins $^{1}$ (D)
}

${ }^{1}$ Escola de Química e Alimentos, Universidade Federal de Rio Grande (FURG), 96170-000, Carreiros, Rio Grande, RS, Brasil. E-mail: evebalbinot@gmail.com. "Corresponding author.

${ }^{2}$ Escola de Química e Alimentos, Universidade Federal de Rio Grande (FURG), Santo Antônio da Patrulha, RS, Brasil.

${ }^{3}$ Departamento de Tecnologia em Alimentos, Universidade Tecnológica Federal do Paraná (UTFPR), Francisco Beltrão, PR, Brasil.

ABSTRACT: Glycosaminoglycans (GAGs) are long-chain polysaccharides that are divided into sulphates and non-sulphates, these being chondroitin sulphate, heparan sulphate, dermatan sulphate, heparin sulphate and the only non-sulphate in the group is hyaluronic acid. GAGs are obtained from animal tissue and by an expensive low-yield extraction process; however, they are highly commercially valued polysaccharides and exploited in the biomedical market. Their disaccharidic composition, chain length and sulfation pattern present great variability depending on the species and extraction factors. GAGs possess immunomodulatory, antioxidant, antiviral, anti-inflammatory, neuroprotective, antiproliferative and anticoagulant properties, functioning as therapeutic agents modulating an array of biological processes. This report presents the general aspects of each GAG, source and extraction process, in addition to the characteristics that give them the most varied therapeutic properties and pharmacological applications.

Key words: glycosaminoglycans, pharmacological applications, antiproliferative, anticoagulant.

Propriedades, potencial bioativo e processos de extração de glicosaminoglicanos: uma visão geral

RESUMO: Os glicosaminoglicanos (GAGs) são polissacarídeos de cadeias longas que se dividem em sulfatados e não sulfatados, sendo estes, sulfato de condroitina, sulfato de heparana, sulfato de dermatana, sulfato de heparina e o único não sulfatado do grupo que é o ácido hialurônico. Os GAGs são encontrados em todo tecido animal, são extraídos por um processo de alto custo e baixo rendimento, no entanto, o material obtido é valorizado comercialmente e amplamente explorado no mercado biomédico. Sua composição dissacarídica, comprimento da cadeia e padrão de sulfatação apresentam grande variabilidade dependendo das espécies e fatores de extração. Os GAGs possuem propriedades imunomoduladoras, antioxidantes, antivirais, anti-inflamatórias, neuroprotetoras, antiproliferativas e anticoagulantes, além de farmacológicas, funcionando como agentes terapêuticos moduladores de uma série de processos biológicos. Este relatório apresenta os aspectos gerais de cada GAG, fonte e processo de extração, além das características que lhes conferem as mais variadas propriedades terapêticas e aplicações farmacológicas.

Palavras-chave: glicosaminoglicanos, aplicações farmacológicas, antiproliferativa, anticoagulante.

\section{INTRODUCTION}

Glycosaminoglycans (GAGs) are part of the family of anionic polysaccharides, composed of repeated disaccharide units of hexosamine (glucosamine and galactosamine) and uronic acid (glucuric acid and iduronic acid) or galactose (found in keratan sulfate) (POMIN, 2015). No connective tissue is found on the surface of animal cells and in the extracellular matrix, with proteoglycans being its main compound. Proteoglycans are combined by two types of molecules: sulfated and non-sulfated GAGs that are covalently linked to the nucleus of the glycosylated protein (NAKANO; BETTI; PIETRASIK, 2010).

GAGs have different densities of negative charge in their structure and are known to bind and regulate different proteins (for example, growth factors, enzymes, cytokines) and can be used in tissues and by-products such as rooster crest, cartilage (bovine trachea) and swine) and umbilical cord (MACCARI et al., 2010; TAVIANATOU et al., 2019).

Due to the sulfate and carboxyl groups, the GAGs are negatively charged and are divided into four main groups according to the sugar molecule 
and the type of bond: are chondroitin sulfate (CS), dermatan sulfate (DS), hyaluronic acid (HA), keratan sulfate (KS), heparin (Hp) and heparan sulfate (HS), are covalently linked via a trisaccharide attached to a serine residue (POMIN, 2015).

GAGs are versatile polysaccharides and their therapeutic properties have been used as in the production of drugs such as: immunomodulators, antioxidants, antivirals, anti-inflammatories, neuroprotectors, antiproliferatives and anticoagulants, in addition to pharmacologicals, (KRICHEN et al., 2017; LIU et al., 2018; NOGUEIRA et al., 2019; (GRAÇA et al., 2020; TAVIANATOU et al., 2019). This review evaluated in general the extraction process and the characteristics of each GAG, and its therapeutical properties.

\section{Conventional method for gag production}

The extraction steps start with delipidation with chloroform and acetone, to remove the fat adhered to the material, followed by drying (NOGUEIRA et al., 2019).

Proteolytic digestion is one of the most important steps, and can be a chemical or enzymatic process only (SAFDAR et al., 2017). The use of amyl alcohol and chloroform helps in removing the protein. However, (AFRATIS et al., 2012) reported that the enzyme-free process is inefficient and affects the yield of GAGs. The extraction of these tissues depends primarily on elimination of most of the protein by digestion with specific proteases (ROSA et al. 2008).

After digestion, the purification or precipitation stage happens; these procedures allow the quantitative recovery of polysaccharides that are not chemically degraded and can be performed with cetylpyridinium chloride (CPC), ethanol, propanol or methanol (AMADO et al., 2016). Organic solvents have different capacity to precipitate GAGs; according to, precipitation is related to the percentage and type of solvent applied and may influence other factors such as molecular mass, charge density and structure. The use of organic solvents is more suitable for the precipitation of sulfates (VOLPI, 2010).

Subsequent to the GAG precipitation stage, the material is separated by centrifugation, filtration, freezing and lyophilization (NAKANO et al. 2012). The separation and purification of GAGs can occur by ion exchange chromatography methods fast protein liquid chromatography (FPLC) (ROSA et al., 2008), lowpressure liquid chromatography (LPLC) (BOUGATEF et al. 2018) and high-performance gel permeation chromatography (HPGPC) (LIU et al., 2018).
Table 1 presents studies with the most varied sources of GAGs, the enzymes used for extraction, the precipitation solvents and the yields obtained in each study. Studies attested that the use of enzymes in the extraction of GAGs improves the quality of the extracted material (BOUGATEF et al., 2018).

\section{Industrial production of Glycosaminoglycans (GAGS)}

The industrial production of GAGs of animal origin, meet the current global demands for $\mathrm{AH}, \mathrm{Hp}$ and $\mathrm{SC}$, despite the limited availability of these tissues (BADRI et al., 2018). The animal tissues used for GAG extraction are: rooster ridges and bovine / porcine eyes for HA, animal cartilage for SC, the SD is mucosa and leather / animal skin tissue, and the Hp of porcine / bovine mast cells. that are reported in the intestinal and lung tissues (DATTA et al., 2019; GRAÇA et al., 2020).

GAGs extracted from animals even in the purification process, there may be presence of undesirable contaminants such as viral particles and prions (contaminant that causes responsible Bovine Spongiform Encephalopathy), facts like this have motivated the development of industrial production methods of GAGs by fermentation cell culture (FU et al.,2015).

\section{Industrial production of glycosaminoglycans (GAGS) from microbial sources}

GAGs biosynthesis consists of the basic steps of precursor synthesis, polymerization and postpolymerization modification (ORŁOWSKA et al., 2015). Each precursor is synthesized from a simple sugar, through a series of steps catalyzed by enzymes. The synthesized precursors are sequentially added to the growing GAG chain through the catalytic action of GAG synthase or glycosyltransferases (MEFTAH et al., 2018). In the release of the GAG synthase polymer backbone, sulfotransferases, epimerases modify saccharide residues, resulting in the structure of GAGs with their complex and varied functional roles (OLIVEIRA et al., 2017).

The commercial production of GAGs from microbial sources has been growing and streptococcus $s p$. have been widely used for the production of HA, in addition to it E. coli $K 4$ and K5 and Pastuerella multicida that produce HA naturally (BADRI et al., 2018). The production of HP, SC, HS, DS sulfates are produced from E. coli K4, E. coli K5, B. subtilis, E. coli BL21, Komagataella pastoris, these are subsequently enzymatically modified to form GAGs (DATTA; LINHARDT; SHARFSTEIN, 2019). 
Table 1 - Studies of glycosaminoglycans, solvents used and yield obtained.

\begin{tabular}{|c|c|c|c|c|c|}
\hline Source & Solvent/ enzyme & $\begin{array}{c}\text { Yield } \\
\text { (dry extract) }\end{array}$ & Precipitation & GAGs & References \\
\hline Rooster crest & $\begin{array}{l}\text { Chloroform-amyl } \\
\text { alcohol }\end{array}$ & $0.6 \%$ & Ethanol & HA & $\begin{array}{c}\text { MEYER \& } \\
\text { PALMER (1934) }\end{array}$ \\
\hline Mollusc & Papain & $0.6 \%$ & Ethanol & HA & $\begin{array}{c}\text { Volpi \& Maccari } \\
\text { (2003) }\end{array}$ \\
\hline Rooster crest & Papain & $2 \%$ & $\mathrm{CPC}$ & HA & $\begin{array}{l}\text { Rosa et al. } \\
\text { (2008) }\end{array}$ \\
\hline Stingray liver & Papain & $0.8 \%$ & Ethanol & HA & $\begin{array}{c}\text { Sadhasivam et al. } \\
\text { (2013) }\end{array}$ \\
\hline Bivalve mollusc & Papain & $4.2 \%$ & Ethanol & HA & $\begin{array}{l}\text { Kanchana et al. } \\
\qquad(2013)\end{array}$ \\
\hline Lumpsucker fish skin & Alkalase & $3 \% *$ & Methanol & CS, DS, HA & $\begin{array}{c}\text { Panagos et al. } \\
\text { (2014) }\end{array}$ \\
\hline Giant snail & Papain & $1 \%$ & Ethanol & DS, HS, Hp & Liu et al. (2018) \\
\hline European eel & Alkalase & $1.22 \%$ & Ethanol & DS, HS, CS & Sila et al. (2018) \\
\hline $\begin{array}{l}\text { Nile tilapia and Pacu } \\
\text { fish skin }\end{array}$ & Alkalase & $\begin{array}{l}0.15 \% \\
0.18 \%\end{array}$ & Ethanol & DS, HS, CS & $\begin{array}{l}\text { Nogueira et al. } \\
\text { (2019) }\end{array}$ \\
\hline $\begin{array}{l}\text { Grey pigfish and } \\
\text { smooth dogfish skin }\end{array}$ & Alkalase & $\begin{array}{l}8.6 \% \\
9.3 \%\end{array}$ & $\mathrm{CPC}$ & DS, CS & $\begin{array}{l}\text { Krichen et al. } \\
\qquad(2017)\end{array}$ \\
\hline
\end{tabular}

CPC, cetylpyridinium chloride; HA, hyaluronic acid; CS, chondroitin sulfate; DS, dermatan sulfate; HS, heparan sulfate; Hp, heparin. ${ }^{*}$ Wet extract.

Many advances have been taking place in this field in order to produce GAGs without animal sources. The yield achieved in these processes is much higher; however, the quality, the low molar mass and the difficulty in consolidating the production of microbial systems with cell lines that meet the desired characteristics for sulfated GAGs is still a challenge for metabolic engineering (BADRI et al., 2018; MEFTAH et al., 2018).

\section{Hyaluronic acid}

In 1934, Karl Meyer and John Palmer described a polysaccharide composed of uronic acid and hexosamine that was obtained from the vitreous humour of bovine eye. The authors proposed the name hyaluronic acid, from the Greek hyaloid (vitreous) and uronic acid (LAURENT, 2020).

Among GAGs, HA has one of the least complex structures. It is an anionic water-soluble polysaccharide comprised of repeating disaccharide units containing $\mathrm{N}$-acetylglucosamine and D-glucuronic acid and $\beta$-D-glucuronic acid, linked via alternating $\beta-(1 \rightarrow 4)$ and $\beta-(1 \rightarrow 3)$ glycosidic bonds (SAFDAR et al. 2017). HA may contain 30,000 repeated disaccharide units and has a high molecular weight $\left(10^{5}-10^{7} \mathrm{Da}\right)$ (TAVIANATOU et al., 2019).

HA has a gelatinous consistency, high viscoelasticity and a high degree of hydration due to the structural characteristics of the molecule (OLIVEIRA et al., 2017). Light scattering studies show that HA is a randomly curved ball with little polydispersity and rigidity (SEVERO et al., 2008).

HA can be reported in various connective tissues of animals, such as skin and cartilage, filling the intercellular spaces, mainly maintaining the flexibility and structure of tissues (HUSSAIN et al., 2017). High concentrations of HA can be found in some organs, such as the umbilical cord, synovial fluid and vitreous humour; however, the highest content is reported in rooster comb (OLIVEIRA et al., 2017).

There is an increasing global demand for HA for medical purposes (SADHASIVAM et al., 2013). In the pharmaceutical, medical and cosmetic areas, HA is used for the production of hydrogels, scaffolds, films, creams, foams and gels (AMADO et al., 2016). Some studies have shown that HA has broad pharmacological applications such as 
antidiabetic (WANG et al., 2018), anti-ageing and skin repair (PAPAKONSTANTINOU et al. 2012), antiproliferative (SADHASIVAM et al. 2013), antiinflammatory (CHEN et al., 2018), wound healing and tissue repair properties (OLIVEIRA, et al., 2017).

HA present in animal tissues is complexed with proteoglycans, making it difficult to obtain HA with a high degree of purity (CHEN et al. 2018). In contrast, HA, being a less complex structure, is the only one of the GAGs under biotechnological production, mainly with Streptococcus $s p$. (BADRI et al., 2018). In 2010 the global demand for medical grade HA was approximately 10 million $\mathrm{kg}$ and the global HA market in this year 2020 is estimated to reach \$ 10.8 billion (FALLACARA et al., 2018; GRAÇA et al., 2020). Currently, study groups are focused on improving the quality of HA with high yield and low cost and reducing extraction time.

\section{Chondroitin sulfate}

$\mathrm{CS}$ is structurally based on $\mathrm{N}$-acetylgalactosamine (GalNAc) as the neutral sugar component (MENDE et al. 2016). CS is a class of long linear polysaccharides, composed of alternating saccharide units of GalNAc and glucuronic acid (GlcA) (TÓTH et al. 2020).

The GalNAc residues may be sulfated at the 4-OH and/or 6-OH positions, while GlcA may be sulfated at the 2-OH position (SOLAKYILDIRIM, 2019). Table 2 shows that according to different sulfation patterns, CS has been mainly divided into four types: CS-A=GlcA-GalNAc (4S), $\mathrm{CS}-\mathrm{C}=\mathrm{GlcA}-$ GalNAc $\quad(6 \mathrm{~S}), \quad \mathrm{CS}-\mathrm{D}=\mathrm{GlcA} \quad(2 \mathrm{~S})-$ GalNAc (6S) and CS-E=GlcA-GalNAc (4S, 6S) (MENDE et al., 2016).

$\mathrm{CS}$ is widely reported on cell surfaces and in the extracellular matrix in the form of proteoglycans. High CS concentrations are found in cartilaginous tissues, within a thin collagen layer with an amorphous substance containing glycoproteins, HA and proteoglycans. Nowadays, the main sources for the production of CS are cartilaginous tissues from cows, pigs and chickens (LIU et al., 2018).

CS encompasses a broad range of applications in several industries such as pharmaceuticals, cosmetics and food. It is used in the treatment of osteoarthritis (LIU et al., 2018) in regenerative medicine (PLACE et al., 2009) and as a dietetic supplement for the prevention and treatment of articulation problems (WANG et al., 2018), among others.

Currently, the availability of commercial $\mathrm{CS}$ is limited by not having a sustainable and riskfree source (viruses, prions, adulteration), facts that affect quality and productivity (POMIN, 2015). In addition, $\mathrm{CS}$ is predominantly produced from bovine or porcine trachea and shark cartilage by a chemical process that consumes a large amount of chemicals (SOLAKYILDIRIM, 2019).

It is estimated a $15 \%$ growth in the CS market, reaching 3 million $\mathrm{kg}$ in 2021 (DATTA; LINHARDT; SHARFSTEIN, 2019). Research is being carried out to develop alternative and safe routes for the production of CS (SOLAKYILDIRIM, 2019).

\section{Dermatan sulfate}

DS is formed by repeating disaccharide units of GalNAc, D-GlcA and L-iduronic acid (IdoA) (VOLPI et al., 2010). DS has O-sulfo groups most commonly found on the 4-position of GalNAc residues and occasionally on the 6-position of GalNAc and the 2-position of L-IdoA acid residues (LINHARDT \& HILEMAN, 1995).

DS has a hybrid structure due to modification of the GlcA residue, involving epimerization of C-5 to form IdoA (VOLPI et al., 2010). Like CS, DS is structurally based on GalNAc

Table 2 - Types of chondroitin sulphate.

\begin{tabular}{lcc}
\hline CS type & Major disaccharides & Other disaccharides \\
\hline CS-A & GlcA-GalNAc (4S) & GlcA-GalNAc/GlcA (2S)-GalNAc \\
CS-C & GlcA-GalNAc (6S) & IdoA-GalNAc (4S, 6S)/GlcA (3S)-GalNAc (4S) \\
CS-D & GlcA (2S)-GalNAc (6S) & IdoA (2S)-GalNAc (4S, 6S)/GlcA (3S)-GalNAc (4S, 6S) \\
CS-E & GlcA-GalNAc (4S, 6S) & IdoA (2S)-GalNAc/GlcA (3S)-GalNAc (6S) \\
\hline
\end{tabular}

Source: Adapted from Zhang et al. (2010). 
as the neutral sugar component. CS-B is an old name for DS, and it is no longer classified as a form of CS (MENDE et al., 2016).

DS is widely spread in mammalian tissue, predominantly reported in dense connective tissues such as tendon and skin (VOLPI et al., 2010). DS organizes and maintains collagen fibrils and their deposition speed (KRICHEN et al., 2018).

DS plays important roles in a diverse set of biological processes including cell proliferation and differentiation, wound healing, and anticoagulant, antithrombotic and anti-inflammatory activity (MENDE et al. 2016) (LINHARDT \& HILEMAN, 1995). DS inhibits clot formation associated with thrombin, acting non-systemically, with fewer collateral effects while selectively inhibiting the thrombin action by heparin cofactor II (HCII) with a profibrinolytic effect. One of its most recent applications is in medical devices and the preparation of artificial tissue (HIGASHI et al., 2015).

\section{Heparin}

Hp was discovered in 1916 by Jay McLean, a student of medicine, and William Henry Howell, a professor, who was the first to use the term heparin, from the Greek 'hepar' or liver, from which it was isolated. It was first tested on humans in 1937 as an anticoagulant, but it was not known exactly how the anticoagulant effect was attributed (XU et al. 2018), In 1968, Abildgaard confirmed these data after isolating antithrombin for the first time (BONNAFFÉ, 2011).

$\mathrm{Hp}$ is a GAG consisting mainly of units of glucosamine (N-acetylated or N-sulfated) and uronic acid (iduronic or glucuronic) joined by 1-4 glycosidic bonds, presenting a complex pattern of substitution by sulfate groups (RANI et al. 2017). In Hp, a high proportion, generally over $80 \%$, of the glucosaminyl residues are $\mathrm{N}$-sulfated. However, the proportion of IdoA in $\mathrm{Hp}$ is large (XU et al. 2018). The molecular weight of $\mathrm{Hp}$ ranges from 5 to $40 \mathrm{kDa}$, with an average of $18 \mathrm{kDa}$ (BONNAFFÉ, 2011; RANI et al., 2017). Hp is the most negatively charged biological macromolecule currently known (XU \& JIN, 2020).

$\mathrm{Hp}$ is reported only in vertebrate and invertebrate tissues, especially the intestine and mucous membranes. Despite its high anticoagulant activity when used as a drug, it is not endogenously reported in the bloodstream, and its biological activity remains unknown to date (KACZMAREK et al., 2017). Commercially, $\mathrm{Hp}$ is extracted from animal sources such as the porcine intestine, with China being the largest producer, serving more than half of the world demand for this anticoagulant (BRITO et al., 2018). In 2015, global sales reached $189,515 \mathrm{~kg}$, with an average rate of $9 \%$ annual increase (BADRI et al., 2018).

$\mathrm{Hp}$ is a natural anticoagulant and antithrombotic, blocking the formation of thromboplastin, a blood clotting factor (TSAI et al. 2017). Coagulation is a defence mechanism of the body that acts to prevent bleeding and complications, involving a series of steps that culminate in the formation of a clot (BRITO et al., 2018). There are countless strategies used to prevent these problems; one which has been widely used is the inhibitor thrombin

The activation of a blood coagulation cascade results in thrombin production and clot formation with its subsequent dissolution. Hp acts through the activation of antithrombin III, an inhibitor of serine protease, which inhibits the activity of the blood coagulation cascade enzymes factor $\mathrm{Xa}$ and factor IIa (TSAI et al., 2017). This catalytic action of Hp is attributed to its ability to bind to basic sites through its negatively charged sulfate and carboxyl groups (BARDDAL et al., 2015).

When bound, Hp causes changes in the antithrombin conformation, making its reactive site more accessible, favouring the binding of thrombin or factor Xa, respectively. Hp, serine protease and the serpin attach to form a ternary complex, which is capable of increasing the speed of the thrombin inhibition reaction by antithrombin up to 1,000 times, after which Hp is released (BONNAFFÉ, 2011; TSAI et al., 2017).

Hp is an anticoagulant and antithrombotic agent used in the prevention and treatment of thromboembolic disorders. However, despite its proven effect and its popularity, the use of Hp as a drug has limitations and can generate numerous adverse effects which can lead to bleeding, osteoporosis, skin rashes, contact dermatitis, urticaria, induced thrombocytopenia and liver failure, among others (TSAI et al., 2017).

\section{Heparan sulfate}

HS was first identified in commercial preparations of $\mathrm{Hp}$ as a low-sulfated heparin byproduct. However, HS, unlike $\mathrm{Hp}$, is present in all tissues with different types of proteoglycans, and it is reported on the mammalian cell surface and in the extracellular matrix (KRICHEN et al., 2018). HS is the most ubiquitous and most diverse among members of the GAG family (GULBERTI et al., 2020).

The molecular weight of HS ranges from 5 to $50 \mathrm{kDa}$, with an average of $29 \mathrm{kDa}$ (LIU et al., 2018). There are 48 possible disaccharide units 
that can form a complete chain of HS with 10-100 disaccharide units (XU et al., 2018). Depending on the cell type, variations in the degree of sulfation and acetylation, and the proportion of these units can occur. HS is usually associated with a protein skeleton forming proteoglycans, present on the cell surface, in the extracellular matrix or in intracellular granules as cited. HS proteoglycans participate in specialized biological mechanisms for cell recognition and signalling (PASQUALE \& PAVONE, 2019).

The understanding of the biological activity of HS proteoglycans is essentially based on the structural diversity of the HS chains. In this way, determination of the sequence of the disaccharide units of HS in embryonic, adult, normal and neoplastic tissues of different pathologies, as well as normal cells and cells maintained in culture, provides information on the biological activity of these compounds (HIGASHI et al., 2015).

The structure of HS is composed of alternating of hexuronic acid (D-GlcA or L- IdoA) and D-glucosamine residues, that can be $\mathrm{N}$-sulfated $\left(\mathrm{NSO}_{3}\right)$ or N-acetylated (NAc) (HIGASHI et al. 2015). HS is a sulfated linear polysaccharide and a biopolymer consisting of variably sulfated repeating disaccharide units (XU, et al. 2020). The repeated disaccharide units are formed alternately by hexosamine (glucosamine) and a non-nitrogenated sugar, uronic acid (D-GlcA or L-IdoA) (HIGASHI et al. 2015). HS usually has at least one sulfate group per disaccharide unit, which can occur in the form of an O-sulfate in position C-2 of IdoA, or in the form of $\mathrm{N}$-sulfate in position $\mathrm{C}-2$ and $\mathrm{O}$-sulfate in position C-6 of glucosamine residues (MOURA et al. 2020).

Due to their large size, the verification of intact HS chains is practically impossible by instrumental analytical tools. Structural characterization of the average sulfation pattern is usually performed after enzymatic hydrolysis of the polymeric chain into the constituent disaccharide units (TÓTH et al., 2020). There are three enzymes with differing specificity for $\mathrm{HS}$ and $\mathrm{Hp}$. The treatment of intact cells with heparin lyase I will partially, but incompletely, trim HS chains from cell surface proteoglycans. Heparin lyase III (heparitinase or heparinase III, E.C. 4.2.2.8) recognizes sites that are common in HS but rare in Hp; these sites contain disaccharides in which the glucuronate residue remains unmodified. Thus, this enzyme cleaves HS into block fragments and removes almost all HS from cell surfaces (GULBERTI et al., 2020).

$\mathrm{HS}$ is a type of GAG that is crucially involved in various biological processes, such as regulation of anticoagulation, inflammation, angiogenesis, cancer, cell recognition, cell adhesion, tissue repair and cell growth control (GULBERTI et al., 2020; TSAI et al., 2017). HS promotes regulation of interaction between cells and their surroundings. Several interactions are important for the growth, development and maintenance of cellular functions (SAFDAR et al. 2017).

\section{Keratan sulfate}

Suzuki and others were the first to describe $\mathrm{KS}$; it was identified as a mucoid-type material containing galactose and glucose besides acetyl and sulfate groups (SUZUKI, 1939). KS is composed of alternating repeating disaccharide units of $\beta-(1,3)$ linked galactose $(\mathrm{Gal})$ and $\beta-(1,4)$-linked GlcNAc with sulfation occurring at the $\mathrm{C} 6$ of both saccharide units (PALMER, 1934).

$\mathrm{KS}$ is the only type of GAG without uronic acid and, in general, its degree of sulfation varies in different tissues. LI et al.(2018)stated that the molecular weight of $\mathrm{KS}$ can vary from $6 \mathrm{kDa}$ to more than $50 \mathrm{kDa}$ and is also dependent on the tissue from which it is extracted. KS chains are typically attached to a protein core, forming proteoglycans (KRICHEN et al. 2018).

$\mathrm{KS}$ is widely distributed and displays a diverse range of functional properties (CATERSON \& MELROSE, 2018). KS in bones serves as a structural component endowed with cell-binding properties (RESTAINO et al. 2016). High amounts of $\mathrm{KS}$ are reported in the extracellular matrix of the cornea and brain (AMADO et al., 2016).

Studies have reported anti-adhesive properties of KS that acts as a barrier to neurite outgrowth and direct axon growth patterns during development and regeneration (CATERSON \& MELROSE, 2018). KS can be used for treating chronic obstructive pulmonary disease (GAO et al. 2016) and the treatment of airway inflammation from bacterial infections (KRICHEN et al., 2018). However, the therapeutic properties of KS have not yet been completely explored, unlike other sulfated GAGs (RESTAINO et al., 2016).

\section{Glycosaminoglycans and their bioactive properties \\ GAGs have remarkable biological activity as co-receptors for a variety of growth factors, cytokines and chemokines (LIU et al., 2018). Their pharmacological effects are related to the molecular size and some structural characteristics such as sulfate clusters, which favour interactions with cationic proteins and guarantee biological activity (AMADO et al., 2016).}


Anticoagulant activity is among the most studied properties of GAGs (BOUGATEF et al., 2019; KRICHEN et al., 2018). This effect is related to the degree of sulfation, its distribution along the polysaccharide chain and the molecular mass, which gives all sulfated GAGs a percentage of anticoagulant activity (LIU et al., 2018).

The most widely applied and commercially known GAG for its anticoagulant efficiency and potential is Hp (BARDDAL et al., 2015). Hp is also known for its antithrombotic effect (NOGUEIRA et al., 2019; BARDDAL et al., 2015); an antithrombin link occurs to the heparin cofactor HCII, which forms complexes with blood clotting enzymes (LIU et al., 2018).

CS is one of the important constituents of bones, due to its essential role in cartilage and other connective tissues; in addition, it is a highly heterogeneous polysaccharide, in terms of molecular mass and degree of sulfation, resulting in various biological activities (KRICHEN et al., 2018).

CS participates in various physiological activities of organisms, such as influencing chondrogenesis, differentiation and cell growth (VALCARCEL et al., 2017) and tumour cell migration (LIU et al., 2018). In addition to these actions, CS can also play important roles in regulating joint function, eliminating free radicals and in anticoagulation (VOLPI et al., 2005). It is used as an alternative therapeutic medication component in cases of osteoarthritis, arthritis, joint pain and sometimes even osteoporosis (VOLPI, 2010).

The negative charges, the heterogeneity of the nature of the disaccharides and the number of disaccharide units of that form DS are the main factors that influence its biological and pharmacological activity. DS has important pharmacological activity, such as antioxidant and neuroprotective actions (KRICHEN et al. 2018; RANI et al. 2017), and antiviral, antiproliferative and anti-tumour activity (BOUGATEF et al. 2018; VOLPI, 2010).

$\mathrm{KS}$ is one of the least explored GAGs; in most studies it is found mixed with CS (POMIN, 2015). KS can be used as an active ingredient in eye drops for treatments aimed at recovering the healthy condition of this tissue in certain visual disorders, since KS is one of the main functional components of the cornea (CATERSON \& MELROSE, 2018).

The medicinal properties demonstrated by HA are diverse: in treatments in the cosmetic area as a moisturizing medium, as a means for encapsulation and controlled release of drugs and cosmetics, in the treatment of degenerative and inflammatory diseases of bone joints, in the replacement of liquid synovial, in the release of chemotherapeutic agents in surgical implants and others (NAKANO et al., 2012). The physicochemical properties of HA, and its ability to form gels in solution, allow it to be used as a vehicle to produce specific media or biologically active serums.

Molar mass is considered the most important property in medical applications that mainly involve bone implants (BORSCHIVER et al., 2018). The molar mass is also responsible for defining the application of HA; the purest ones are used for pharmacological applications.

The pharmacological properties that make GAGs important therapeutic agents are related to structural characteristics such as molar mass and sulfate groupings.

\section{CONCLUSION}

The synthetic and chemoenzymatic substances of GAGs, although complex, have advanced as substitutes for conventional extraction methods. The techniques add organic reactions; although, chemical synthesis has been commercially well-defined is a time-consuming process, requiring many steps in addition to being extremely expensive and with low yield. Research has advanced in the direction of producing GAGs by fermentative processes, without animals. GAGs are natural products of high molecular weight, their recombinant production presents unique challenges compared to natural products of small molecular weight. The studies are carried out with the objective of facilitating the switch to non-animal GAG production methods; however, it is a great challenge to obtain these polysaccharide complexes. Despite obtaining GAGs are increasingly required in several applications in tissue engineering, as a vehicle for the transport of medicines, wide pharmacological application, which properties make it a versatile polysaccharide with important biological activity, as they are linked to the bond and sequestration of growth factors, cell division, migration and other important aspects of cell physiology. GAGs have many properties to be marked, with great challenges to be overcome in new extraction methods and possibly a future with GAGs without animals, adapted for higher activities, high yield and a shorter production time, are not far from us.

\section{ACKNOWLEDGMENTS}

And was financed in part by the Coordenação de Aperfeiçoamento de Pessoal de Nível Superior (CAPES), Brasil Finance code 88882.443823/2019-01. 


\section{DECLARATION OF CONFLICT OF INTEREST}

We have no conflict of interest to declare.

\section{AUTHORS' CONTRIBUTIONS}

All authors contributed equally for the conception and writing of the manuscript. All authors critically revised the manuscript and approved of the final version.

\section{REFERENCES}

AFRATIS, N. et al. Glycosaminoglycans: Key players in cancer cell biology and treatment. FEBS Journal, 2012. v.279, n.7, p.1177-1197.

AMADO, I. R. et al. Cheese whey: A cost-effective alternative for hyaluronic acid production by Streptococcus zooepidemicus. Food Chemistry, 2016. v.198, p.54-61. Available from: <http://dx.doi. org/10.1016/j.foodchem.2015.11.062>.

BADRI, A. et al. The road to animal-free glycosaminoglycan production : current efforts and bottlenecks. Current Opinion in Biotechnology, 2018. v.53, p.85-92. Available from: $<$ https://doi. org/10.1016/j.copbio.2017.12.018>.

BONNAFFÉ, D. Bioactive synthetic heparan sulfate and heparin derivatives: From long fragments mimetics to chimeras. Comptes Rendus Chimie, 2011. v.14, n.1, p.59-73.

BORSCHIVER, S. et al. On the Map Technology roadmap for hyaluronic acid and its derivatives market. Biofuels bioproducts \& biorefining, 2018. p.1-10.

BOUGATEF, A. H. et al. Chondroitin sulfate/dermatan sulfate from Corb (Sciaena umbra) Skin: Purification, Structural Analysis and Anticoagulant Effect. Carbohydrate Polymers, 2020. v.164, p.131-139. Available from: <https://doi.org/10.1016/j. carbpol.2018.05.019>.

BRITO, A. S. et al. Anti-IIa activity and antitumor properties of a hybrid heparin / heparan sulfate-like compound from Litopenaeus vannamei shrimp. International Journal of Biological Macromolecules, 2018. v.118, p.1470-1478. Available from: $<$ https://doi.org/10.1016/j.ijbiomac.2018.06.143>.

CATERSON, B.; MELROSE, J. Keratan sulfate, a complex glycosaminoglycan with unique functional capability. Glycobiology, 2018. v.28, n.4, p.182-206.

DATTA, P.; LINHARDT, R.J.; SHARFSTEIN, S.T. Industrial production of glycosaminoglycans. Encyclopedia of Microbiology, 2019. n. c, p.681-690.

FALLACARA, A. et al. Hyaluronic acid in the third millennium. Polymers, 2018. v.10, n.7.

GAO, C. et al. A keratan sulfate disaccharide prevents inflammation and the progression of emphysema in murine models. American Journal of Physiology - Lung Cellular and Molecular Physiology, 2016. v.312, n.2, p.L268-L276.

GRAÇA, M. F. P. et al. Hyaluronic acid—Based wound dressings: A review. Carbohydrate Polymers, 2020. v.241.
GULBERTI, S. et al. The role of heparan sulfate maturation in cancer: A focus on the 3O-sulfation and the enigmatic 3O-sulfotransferases (HS3STs). Seminars in Cancer Biology, 2020. v.62, p.68-85. Available from: <https://doi.org/10.1016/j. semcancer.2019.10.009>.

HIGASHI, K. et al. Composition of glycosaminoglycans in Elasmobranchs including Several Deep-Sea Sharks : Identification of Chondroitin / Dermatan Sulfate from the Dried Fins of Isurus oxyrinchus and Prionace glauca. Plos one, 2015. p.1-15.

HUSSAIN, Z. et al. Hyaluronic Acid-Based Biomaterials : A Versatile and Smart Approach to Tissue Regeneration and Treating Traumatic, Surgical, and Chronic Wounds. Polymer Reviews ISSN:, 2017. v.57, p.594-630. Available from: <http://dx.doi.org /10.1080/15583724.2017.1315433>

KACZMAREK, B. et al. The cells viability study on the composites of chitosan and collagen with glycosaminoglycans isolated from fish skin. Materials Letters, 2017. v.206, p.166-168. Available from: <http://dx.doi.org/10.1016/j.matlet.2017.07.022>.

KRICHEN, F.; GHLISSI, Z.; et al. In vitro and in vivo anticoagulant activity and toxicological studies of marine sulfated glycosaminoglycans. Experimental and Toxicologic Pathology, 2017. v.69, n.1, p.45-53. Available from: <http://dx.doi. org/10.1016/j.etp.2016.11.002>

VOLPI, Nicola; et al. Purification, structural characterization and antiproliferative properties of chondroitin sulfate / dermatan sulfate from tunisian fish skins. International Journal of Biological Macromolecules, 2017. v.95, p.32-39. Available from: <http:// dx.doi.org/10.1016/j.ijbiomac.2016.10.108>

LAURENT, T. C. "The tree": hyaluronan research in the 20th century. [S.1.], 2020. Available from: $<$ https://www.glycoforum. gr.jp/article/06A1.html>

LIU, Jie; et al., Structural analysis and biological activity of a highly regular glycosaminoglycan from Achatina fulica. Carbohydrate Polymers, 2018. v.181, p.433-441.

MACCARI, F.; et al.,. Structural characterization of chondroitin sulfate from sturgeon bone. Carbohydrate Research, 2010. v.345, n.11, p.1575-1580. Available from: <http://dx.doi.org/10.1016/j. carres.2010.05.016>.

MEFTAH, S. et al. Effect of dry-sausage starter culture and endogenous yeasts on Aspergillus westerdijkiae and Penicillium nordicum growth and OTA production. LWT - Food Science and Technology, 2018. v.87, p.250-258. Available from: <http:// dx.doi.org/10.1016/j.1wt.2017.08.090>

MENDE, M. et al. Chemical synthesis of glycosaminoglycans. Chemical Reviews, 2016. v.116, n.14, p.8193-8255.

MOURA, H. C. et al. Characteristics and applications of glycosaminoglycans: use of by-products of the food industry DOI:10.34115/basrv4n3-053. Brazilian Applied Science Review 1422, 2020. v.4, n.3, p.1421-1436.

NAKANO, Takuo et al. Extraction, isolation and analysis of chondroitin sulfate from broiler chicken biomass. Process Biochemistry, 2012. v.47, n.12, p.1909-1918. Available from: $<$ http://dx.doi.org/10.1016/j.procbio.2012.06.018>.

Ciência Rural, v.51, n.7, 2021. 
NOGUEIRA, A. V et al. Viscera of fi shes as raw material for extraction of glycosaminoglycans of pharmacological interest. International Journal of Biological Macromolecules, 2019. v.121, p.239-248. Available from: <https://doi.org/10.1016/j. ijbiomac.2018.09.156>.

OLIVEIRA BARDDAL, H. P. DE et al. Anticoagulant activity of native and partially degraded glycoglucuronomannan after chemical sulfation. International Journal of Biological Macromolecules, 2015. v.80, p.328-333. Available from: <http:// dx.doi.org/10.1016/j.ijbiomac.2015.06.051>.

OLIVEIRA, S. DE et al. Production and characterization of bacterial cellulose membranes with hyaluronic acid from chicken comb. International Journal of Biological Macromolecules, 2017. v.97, p.642-653.

ORŁOWSKA, A. et al. Suitability of using serum hialuronic acid concentrations in the diagnosis of canine liver fibrosis. 2015. v.18, n.4, p.873-878.

PAPAKONSTANTINOU, E.; et al.,Hyaluronic acid: A key molecule in skin aging. Dermato-Endocrinology, 2012. v.4, n.3.

PASQUALE, V. DE; PAVONE, L. M. Heparan sulfate proteoglycans: The sweet side of development turns sour in mucopolysaccharidoses. Biochimica et Biophysica Acta Molecular Basis of Disease, 2019. v.1865, n.11, p.165539. Available from: $<$ https://doi.org/10.1016/j.bbadis.2019.165539>.

POMIN, V. H. A Dilemma in the glycosaminoglycan-based therapy: synthetic or naturally unique molecules? Medicinal Research Reviews, 2015. v.35, n.6, p.1195-1219.

RANI,A.;BARUAH, R.; GOYAL,A. Physicochemical, antioxidant and biocompatible properties of chondroitin sulphate isolated from chicken keel bone for potential biomedical applications. Carbohydrate Polymers, 2017. v.159, p.11-19. Available from: $<$ http://dx.doi.org/10.1016/j.carbpol.2016.12.015>.

RESTAINO, R. F. et al. A multi-analytical approach to better assess the keratan sulfate contamination in animal origin chondroitin sulfate Odile. Analytica Chimica Acta, 2016. v.16, n.2017, p.4 32. Available from: <http://dx.doi.org/10.1016/j.aca.2016.12.005>.

SADHASIVAM, G. et al. Isolation and characterization of hyaluronic acid from the liver of marine stingray Aetobatus narinari. International Journal of Biological Macromolecules,
2013. v.54, p.84-89. Available from: <http://dx.doi.org/10.1016/j. ijbiomac.2012.11.028>

SAFDAR, M. H. et al. New developments and clinical transition of hyaluronic acid-based nanotherapeutics for treatment of cancer : reversing multidrug resistance, tumour-specific targetability and improved anticancer efficacy. Artificial Cells, Nanomedicine, and Biotechnology, 2017. v.0, n.0, p.1-14. Available from: <https:// doi.org/10.1080/21691401.2017.1397001>.

SEVERO, D. R. C. et al. Antioxidant activity of hyaluronic acid extracted from chicken crest. Ciência Rural, 2008. v.38, n.9, p.2593-2598.

SILA, Assaâd et al. Studies on European eel skin sulfated glycosaminoglycans: Recovery, structural characterization and anticoagulant activity. International Journal of Biological Macromolecules, 2018. v.115, p.891-899. Available from: $<$ https://doi.org/10.1016/j.ijbiomac.2018.04.125>.

SOLAKYILDIRIM, K. Recent advances in glycosaminoglycan analysis by various mass spectrometry techniques. Analytical and Bioanalytical Chemistry, 2019. p.3731-3741.

TAVIANATOU, A. G. et al. Hyaluronan : molecular size-dependent signaling and biological functions in inflammation and cancer. The FEBS Journal 286, 2019. v.286, p.2883-2908.

TÓTH, G. et al. Salt gradient chromatographic separation of chondroitin sulfate disaccharides. Journal of Chromatography A, 2020. v.1619, p.2-7.

TSAI, C. T.;et al.,. Synthetic heparin and heparan sulfate: probes in defining biological functions. Current Opinion in Chemical Biology, 2017. v.40, p.152-159. Available from: <http://dx.doi. org/10.1016/j.cbpa.2017.09.012>.

VALCARCEL, J. et al. Glycosaminoglycans from marine sources as therapeutic agents. Biotechnology Advances, 2017. v.35, n.6, p.711-725. Available from: $<$ http://dx.doi.org/10.1016/j.biotechadv.2017.07.008>.

WANG, Lingchong; DI, L.; WU, H. Abundance of saccharides and scarcity of glycosaminoglycans in the soft tissue of clam , Meretrix meretrix (Linnaeu). Acta Histochemica, 2018. v.120, n.6, p.551-557. Available from: <https://doi.org/10.1016/j. acthis.2018.07.001>.

XU, K.; JIN, L. The role of heparin/heparan sulphate in the IFN- $\gamma$ led Arena. Biochimie, 2020. v.170, p.1-9. 